\title{
Hubungan Antara Pengetahuan Manajemen Dan Komitmen Dengan Kinerja Pengurus Pusat Pendidikan dan Latihan Pelajar (PPLP) Di Sumatera Utara
}

\author{
Imran Akhmad \\ Correspondence: Fakultas Ilmu Keolahragaan, Universitas Negeri Medan, \\ Medan, Indonesia \\ E-mail: imranakhmad73@gmail.com
}

\begin{abstract}
Abstrak
Penelitian ini bertujuan untuk mengetahui hubungan antara pengetahuan manajemen dan komitmen terhadap kinerja pengurus Pusat Pendidikan dan Latihan Pelajar (PPLP) di Indonesia. Disamping itu penelitian ini juga untuk mengetahui hubungan antara pengetahuan manajemen dan komitmen secara bersama-sama terhadap kinerja pengurus PPLP di Indonesia. Penelitian ini dilaksanakan di Sumatera Utara pada bulan Februari sampai Juni 2016. Metode penelitian yang dipergunakan adalah metode deskriptip dengan korelasional. Teknik pengambilan sampel dengan menggunakan proporsional random sampel yang berjumlah 40 orang.Teknik analisis yang dipergunakan adalah teknik regresi. Hasil penelitian ini menyimpulkan bahwa : (1) Terdapat hubungan yang signifikan antara pengetahuan manejemen dengan kinerja pengurus PPLP di Sumatera Utara dengan menunjukkan $t_{\text {hit }}=43,28>t_{\text {tab }} 1.68$, (2) Terdapat hubungan yang signifikan antara komitmen dengan kinerja pengurus PPLP di Sumatera Utara dengan menunjukkan $t_{\text {hit }}=79.3>t_{\text {tab }} 1.81$, (3) Terdapat hubungan yang signifikan secara bersama-sama antara Pengetahuan Manajemen dan Komitmen dengan kinerja pengurus PPLP di Sumatera Utara dengan menunjukkan $t_{\text {hit }}=4.94>t_{\text {tab }}$ sebesar 1.81 .
\end{abstract}

\section{Kata Kunci: Kinerja, Komitmen dan Pengetahuan Manajemen}

\section{Pendahuluan}

Pembinaan olahraga di Indonesia menurut Harsuki dkk (1996) telah diarahkan dan dilakukan dengan berbagai arah melalui: (1) Sekolah-sekolah atau pelajar (mulai dari pendidikan dasar sampai pendidikan tinggi), (2) induk-induk cabang olahraga, (3) organisasi dan perkumpulan olahraga, dan (4) organisasi di masyarakat. Arah tersebut berguna untuk mengidentifikasi khalayak sasaran sehingga memudahkan mobilisasi sumber daya untuk pembinaan dalam jangka panjang. Berdasarkan arah tersebut di atas maka akan diperoleh model pembinaan yang tepat diterapkan di Indonesia guna mencapai sistem pembinaan olahraga nasional secara optimal.

Upaya pemerintah telah dilakukan dengan mendirikan model pembinaan di kalangan pelajar yang disebut dengan Diklat pelajar di beberapa propinsi di Indonesia dengan objek sasaran pelajar terutama siswa yang disebut dengan Pusat Pendidikan dan Latihan Pelajar (PPLP). Pelajarlah sebagai sumber daya manusia yang tepat untuk menjadi sasaran untuk mencari cikal bakal munculnya atlet berprestasi di masa mendatang. Hal ini didasari pada kuantitas jumlah pelajar di 
Indonesia cukup besar sehingga memiliki peluang yang sangat besar munculnya atlet-atlet yang potensial apabila dibina secara berjenjang dan berkesinambungan.

Sejauh ini ternyata diklat yang didirikan dengan visi dan misi yang baik dalam mengembangkan tugas moral yang besar, ternyata masih memiliki kontribusi yang kecil terhadap munculnya atlet berprestasi. Kondisi ini perlu diamati dan dievaluasi faktor-faktor apa saja yang terbukti tidak memiliki kinerja yang baik. Kedudukan organisasi didalamnya tertuang pada kualitas manajemen dan administrasi, penempatan dan kinerja pengurus. Apakah kesemua ini telah bekerja secara optimal serta berbagai aspek yang berhubungan secara langsung atau tidak langsung pada mutu kelembagaannya dalam mengemban tugas sebagai fasilitator proses pembinaan.

Uraian di atas menunjukkan bahwa faktor yang berperan penting dalam kemajuan organisasi adalah kinerja pengurusnya. Pengurus merupakan pengelola kehidupan organisasi, harus mampu menjamin dan menjalankan tugas dan kegiatan-kegiatan yang dilaksanakan dalam PPLP adalah memenuhi pencapaian target PPLP.

Pengetahauan manajemen merupakan suatu bekal bagi pengurus suatu organisasi dalam menjalankan roda organisasi. Dengan modal pengetahuan tentang manajemen, dengan sendirinya seorang pengurus akan menyadari tugas dan tanggung jawabnya serta kedudukannya dalam sebuah organisasi. Dengan demikian bahwa variabel pengetahuan manajemen diduga sangat berpengaruh terhadap kinerja pengurus organisasi dalam hal ini PPLP.

Disamping itu, variabel lain yang penting juga bagi seorang pengurus komitmen terhadap organisasi yang diembankannya. Komitmen merupakan sikap anggota organisasi terhadap organisasinya. Komitmen berhubungan dengan aspek kepribadian seseorang yang diwujutkannya dalam perilaku. Dengan memiliki komitmen yang baik, seseorang akan menyertakan suatu tekat untuk melaksanakan sesuatu. Dengan komitmen juga bahwa seseorang akan memiliki itikat yang baik terhadap sebuah organisasi dimana ia akan mengabdikan dirinya untuk organisasi dan selalu berupaya untuk menjadi lebih baik. Dengan memiliki komitmen yang tinggi, maka seorang pengurus akan bertanggung jawab terhadap tugas individu dan pada gilirannya turut bertanggung jawab terhadap tujuan organisasi. Oleh sebab itu juga bahwa variabel komitmen diduga berpengaruh terhadap kinerja pengurus PPLP di Indonesia.

Sebuah PPLP dapat dikatakan baik salah satunya indikatornya dapat dilihat dari kuantitas prestasi siswa di berbagai even. Uraian diatas membuktikan bahwa, peran pengurus organisasi yang dilihat melalui kinerjanya, sangatlah besar dalam menentukan keberhasilan pelajar. Oleh sebab itu perlu kiranya diadakan penelitian tentang faktor-faktor yang menentukan kinerja pengurus lembaga olahraga pelajar dalam hal ini Pusat Pendidikan dan Latihan Olahraga Pelajar yaitu Pengetahuan Manajemen dan komitmen. Tujuan dalam penelitian ini adalah untuk mengetahui (1) Hubungan antara pengetahuan manajemen dengan kinerja pengurus Pusat Pendidikan dan Latihan Pelajar di Sumut? (2) Hubungan antara komitmen dengan kinerja pengurus Pusat Pendidikan dan Latihan Pelajar di Sumut Dan (3) Hubungan antara pengetahuan manajemen dan komitmen secara

PJKR_

http://jurnal.unimed.ac.id/2012/index.php/jpehr/index 
bersama-sama dengan kinerja pengurus Pusat Pendidikan dan Latihan Pelajar di Sumut?

\section{Pustaka}

Kinerja merupakan sesuatu hal yang sangat penting dalam kehidupan berorganisasi, dalam hal ini berkaitan dengan prestasi kerja seseorang terhadap tugas dan tanggung jawabnya dalam suatu organisasi (Wahyudi: 2016). Kinerja merupakan terjemahan dari kata "performance" yang berarti kemauan dan kemampuan untuk melakukan suatu pekerjaan pada kurun waktu tententu (Fadli; 2016). Serto (1997) mendefenisikan kinerja sebagai kegiatan produktif masa lampau seseorang yang memberikan kontribusi pada pencapaian tujuan sistem manajemen. Sedangkan Imran (2013) mendefenisikan kinerja sebagai hasil kerja dan tingkah laku. Hal ini memang terlihat bahwa kinerja merupakan faktor penting dalam menentukan keberhasilan.

Amstrong dan Baron (1998) mengungkapkan bahwa kinerja seseorang dipengaruhi oleh empat faktor, yaitu; 1) faktor personal, meliputi keterampilan individu, kompetensi, motivasi dan rekrutmen, faktor kepemimpinan yang berkualitas dan pemberian motivasi, bimbingan, dorongan yang diberikan, 2) faktor sistem pekerjaan, 3) faktor situasional meliputi perubahan dan penekanan dan 4) faktor internal dan eksternal.

Dari uraian di atas dapat di tarik kesimpulan bahwa pekerjaan seorang pengurus sangat berhubungan dengan kegiatan manajerial, sehingga inisiatifinisiatif tertentu banyak diperlukan untuk melakukan perberdayaan staf yang dipengurusnya dengan orientasi demi kemajuan organisasi.

Pengetahuan Jujun (1988) pada dasarnya merupakan segenap apa yang diketahui tentang suatu objek, dan hasanah mental yang secara langsung atau tidak langsung turut memperkaya kehidupan manusia. Sebab secara alamiah, Sejak mulai lahir manusia, mepunyai sifat ingin tahu tentang sesuatu yang ada disekitar lingkungannya. Kuat lemahnya rasa ingin tahunya manusia, ditentukan oleh kemauam yang berasan dari dalam diri tiap individu dan interpretasi lingkungan dimana dia berada.

Aspek-aspek pengetahuan menurut Bloom (1981) berisi tentang; (1) pengetahuan spesipik, terdiri dari pengetahuan yang bersifat terminologi dan pengetahuan spesifik tentang fakta-fakta spesifik, (2) pengetahuan yang menyangkut cara-cara dan makna-makna spesifik, yang meliputi pengetahuan tentang konvensi/kesepakatan, pengetahuan tentang kecenderungan dan urutan, pengetahuan tentang klasifikasi dan kategori, pengetahuan tentang kriteria dan pengetahuan tentang metodologi, (3) pengetahuan universal dan abstrak dalam suatu klasifikasi dan kategori, pengetahuan tentang kriteria dan pengetahuan tentang metodologi, (4) pengetahuan universal dan abstrak dalam suatu bidang, meliputi; Pengetahuan tentang prinsip-prinsip dan generalisasi serta pengetahuan tentang teori dan struktur.

Sedangkan manajemen merupakan proses yang dilakukan untuk mendapatkan hasil melalui orang lain. Hal ini sesuai dengan pendapat Robbin 
(1988) bahwa manajemen adalah sebagai proses mendapatkan hasil secara efisien dan melalui orang lain. Kemudian Foillet dalam Handoko (2001) mengungkapkan bahwa manajemen adalah seni untuk menyelesaikan pekerjaan melalui orang lain. Hal ini menunjukkan bahwa para pengurus organisasi mencapai tujuan-tujuan organisasi melalui pengaturan orang-orang lain untuk melaksanakan berbagai pekerjaan yang diperlikan

Sedangkan Terry dalam Hasibuan (2005), membagi fungsi manajemen menjadi; 1) planning (perencanaan), 2) organizing (pengorganisasian), 3) Actuating (penggerak), 4) controling (pengawasan). Fungsi-fungsi dari manajemen yang dikemukakan para ahli menajemen sepakat bahwa, manajemen merupakan suatu proses yang diarahkan pada pencapaian tujuan dengan cara-cara tertentu.

Dengan demikian dapat disimpulkan bahwa pengetahuan manajemen merupakan hasil proses pemikiran manusia tentang aktivitas yang mendayagunakan sumberdaya dalam sebuah organisasi, dalam rangka mencapai tujuan yang diperolehnya dari fakta-fakta melalui panca indera yang selanjutnya membentuk sikap dan tindakan.

Mathieu dan Zagac dalam Luthan (1995) menyatakan bahwa komitmen akan memberikan dukungan positif terhadap hasil yang diharapkan organisasi seperti terhadap performansi, menghindari pekerja berhenti dan ketidak hadiran kerja. Dessler (2003) mengemukakan bahwa komitmen adalah identifikasi pekerja dan menyatakan untuk mencapai misi perusahaan. Sehingga komitmen sangat berperan penting dalam penataan organisasi. Dengan komitmen juga bahwa komitmen merupakan suatu itikat yang baik terhadap suatu organisasi dimana dapat mengabdikan dirinya untuk oraganisasi dan selalu berupaya untuk menjadi lebih baik. Komitmen menurut Kuhn dan Geis dalam Siswanto (1996) meliputi; 1) komitmen inti yang mendukung dominasi kelompok, 3) komitmen penuh perhitungan yang didasarkan pada kaidah-kaidah untung rugi bagi diri sendiri serta komitmen 3) angin-anginan yang ditentukan dominasi sesaat (status quo).

Berdasarkan uraian di atas, dapat disimpulkan bahwa komitmen merupakan pernyataan seseorang untuk mengabdikan dirinya dalam melaksanakan tugas atas nama organisasi dengan maksud mencapai tujuan yang diinginkan. Komitmen pengurus lembaga olahraga pelajar merupakan komitmen yang dimiliki oleh pengurus organisasi tersebut untuk melakukan tugas hariannya dengan serius dengan kategori atas lima jenis terhadap, olahragawan, organisasi, diri sendiri, orang lain dan tugas.

\section{Metode}

Penelitian ini dilaksanakan pada Pusat Pendidikan dan Latihan Pelajar (PPLP) di Sumatera Utara. Penelitian ini dilaksanakan pada bulan Februari sampai bulan Juni 2016. Penelitian menggunakan metode survey dengan pendekatan korelasional yaitu menghubungkan satu variabel dengan variabel lain untuk memahami suatu fenomena dengan cara menentukan tingkat atau derajat hubungan di antara variabel-variabel tersebut.

PJKR_

http://jurnal.unimed.ac.id/2012/index.php/jpehr/index 
Populasi teoritis penelitian ini adalah seluruh pengurus Pusat Pendidikan dan Latihan Pelajar (PPLP) di Sumatera Utara yang memiliki kebijakan dalam pengambilan keputusan yang berjumlah 52 orang. Dasar pengambilan sampel dalam penelitian ini yaitu dengan menggunakan teknik random sampel yang berjumlah 40 orang. Sedangkan dalam uji coba instrumen di lakukan pada 30 orang juga pada pengurus cabang olahraga di Medan.

Teknik analisis data penelitian dilakukan dengan statistik deskriptif dan statistik inferensial. Statistik inferensial digunakan untuk menguji hipotesisi dengan menggunakan teknik analisis regresi dan korelasi sederhana dan teknikanalisis regresi dan korelasi ganda (Sutrinso Hadi; 1993). Sebelum pengujian hipotesisi terlebih dahulu dilakukan uji persyaratan analisis yang terdiri dari: Uji normalitas dengan menggunakan uji liliefor dan uji homogenitas dengan menggunakan uji bartlet (Sudjana; 2002).

\section{Pembahasan}

1. Hipotesis pertama

Anava Regresi Linier Sederhana Y atas X1 dengan Persamaan Regresi $\hat{Y}$ $=66,99+2,55 \mathrm{X}_{1}$

\begin{tabular}{lrrrrrr}
\hline \multicolumn{1}{c}{ Sbr. Var } & \multirow{2}{*}{ DK } & \multirow{2}{*}{ JK } & \multirow{2}{*}{ RJK } & \multirow{2}{*}{ Fh } & \multicolumn{2}{c}{ Ft } \\
\cline { 6 - 8 } Total (T) & 40 & 2232564,22 & & & & $\mathbf{0 . 0 5}$ \\
\hline Reg (a) & 1 & 1113223 & 1113223 & & & \\
Reg (b/a) & 1 & 6002.077 & 6002.077 & $1971.322^{*}$ & 4.10 & 7.35 \\
Sisa (S) & 38 & 115.6985 & 3.044696 & & & \\
\hline Tuna Cocok (TC) & 16 & -4233.13 & -264.571 & $-1.33842^{\text {ns }}$ & 3.03 & 2.19 \\
Galat (G) & 22 & 4348.833 & 197.6742 & & & \\
\hline
\end{tabular}

Hasil Perhitungan Korelasi $\mathrm{X}_{1}$ dengan $\mathrm{Y}$

\begin{tabular}{cccccccc}
\hline \multirow{2}{*}{ Korelasi } & \multirow{2}{*}{$\mathbf{n}$} & $\mathbf{R}$ & \multirow{2}{*}{$\mathbf{r}^{\mathbf{2}}$} & $\mathbf{t}_{\text {hit }}$ & \multicolumn{3}{c}{$\mathbf{t}_{\text {tab }}$} \\
\hline $\mathrm{X}_{1}$ dengan $\mathrm{Y}$ & 40 & 0.99 & 0.98 & 43,28 & $\mathbf{0 . 0 5}$ & $\mathbf{0 . 0 1}$ \\
\hline
\end{tabular}

Berdasarkan uraian di atas menunjukkan $t_{\text {hit }}$ sebesar 43,28 lebih besar dari pada $\mathrm{t}$ tabel 1.68 , maka dapat disimpulkan bahwa $\mathrm{H}_{0}$ ditolak yang berarti terdapat hubungan yang signifikan antara pengetahuan manajemen dengan kinerja engurus PPLP.

Berdasarkan koefisien korelasi $\mathrm{r}_{\mathrm{y} 1}$ tersebut di atas diperoleh koefisien determinasi 0.98. Hal ini berarti bahwa 98\% variasi kinerja pengurus PPLP dapat dijelaskan oleh variasi pengetahuan manajemen.

PJKR_

http://jurnal.unimed.ac.id/2012/index.php/jpehr/index 
2. Hipotesis kedua

Anava Regresi Linier Sederhana $\mathrm{Y}$ atas $\mathrm{X}_{2}$ dengan Persamaan Regresi $\hat{\mathrm{Y}}=$ $226.47+2,85 \mathrm{X}_{2}$

\begin{tabular}{lrrrrrr}
\hline \multicolumn{1}{c}{ Sbr. Var } & DK & JK & RJK & Fh & O.05 & $\mathbf{0 . 0 1}$ \\
\hline Total & 40 & 2232564,23 & & & & \\
\hline Reg (a) & 1 & 1113223 & & & & \\
\hline Reg (b/a) & 1 & 5744.678 & 5744.678 & & & \\
\hline Sisa & 38 & 373.097 & 9.818342 & 585.0966 & 4,10 & 7.35 \\
\hline Tuna Ck & 16 & -3890.69 & -243.168 & & & \\
\hline Galat & 22 & 4263.783 & 193.8083 & -1.25468 & 3.03 & 2.19 \\
\hline
\end{tabular}

Hasil Perhitungan Korelasi $\mathrm{X}_{2}$ dengan $\mathrm{Y}$

\begin{tabular}{cccccrc}
\hline \multirow{2}{*}{ Korelasi } & $\mathbf{n}$ & $\mathbf{r}$ & \multirow{2}{*}{$\mathbf{r}^{\mathbf{2}}$} & thit & \multicolumn{2}{c}{$\mathbf{t}_{\text {tab }}$} \\
\hline $\mathrm{X}_{2}$ dengan $\mathrm{Y}$ & 40 & 0.97 & 0.94 & 79.30 & 1.81 & $\mathbf{0 . 0 1}$ \\
\hline
\end{tabular}

Pada tebel di atas menunjukkan $t_{\text {hit }}$ sebesar 79.3 lebih besar dari pada $t$ tabel 1.81, maka dapat disimpulkan bahwa $\mathrm{H}_{0}$ ditolak yang berarti terdapat hubungan yang signifikan antara komitmen dengan kinerja pengurus PPLP.

Berdasarkan koefisien korelasi $\mathrm{r}_{\mathrm{y} 2}$ tersebut di atas diperoleh koefisien determinasi 0.94. Hal ini berarti bahwa 94\% variasi kinerja pengurus PPLP dapat dijelaskan oleh variasi komitmen.

\section{Hipotesis ketiga}

Anava Regresi Linier Sederhana $\mathrm{Y}$ atas $\mathrm{X}_{2}$ dengan Persamaan Regresi $\hat{\mathrm{Y}}=$ $121.14+2.58 \mathrm{X}_{1}+-0.03 \mathrm{X}_{2}$

\begin{tabular}{lllllll}
\multicolumn{1}{c}{ Sbr. Var } & DK & JK & & Fh & \multicolumn{2}{c}{ Ft } \\
\cline { 3 - 6 } Total (T) direduksi & 40 & 1967,67 & & & \\
\hline Regresi & 2 & 6117.78 & & & \\
\hline Sisa & 38 & 4150.11 & 8.94 & 3.19 & 4.38 \\
\hline
\end{tabular}

Hasil Perhitungan Korelasi $\mathrm{X}_{1}$ dan $\mathrm{X}_{2}$ dengan $\mathrm{Y}$

\begin{tabular}{cccccrrr}
\hline \multirow{2}{*}{ Korelasi } & \multirow{2}{*}{$\mathbf{n}$} & $\mathbf{R}$ & \multirow{2}{*}{$\mathbf{R}^{\mathbf{2}}$} & \multirow{2}{*}{$\mathbf{F}_{\text {hit }}$} & \multicolumn{2}{c}{$\mathbf{F}_{\text {tab }}$} \\
\cline { 5 - 8 } & & & & & & $\mathbf{0 . 0 5}$ & $\mathbf{0 . 0 1}$ \\
\hline $\mathrm{Ry}_{12}$ & 40 & 0.57 & 0.32 & 8.94 & 4.10 & 4.38 \\
\hline
\end{tabular}

Pada tebel di atas menunjukkan $\mathrm{F}_{\text {hit }}$ sebesar 8.94 lebih besar dari pada $\mathrm{F}$ tabel 4.10, maka dapat disimpulkan bahwa $\mathrm{H}_{0}$ ditolak yang berarti terdapat hubungan yang signifikan antara pengetahuan manajemen $\left(\mathrm{X}_{1}\right)$ dan komitmen $\left(\mathrm{X}_{2}\right)$ dengan kinerja pengurus PPLP (Y).

Berdasarkan koefisien korelasi ganda $\mathrm{R}_{\mathrm{y} 12}$ tersebut di atas diperoleh koefisien determinasi $\left(\mathrm{R}^{2}\right)$ sebesar 0.32 . Hal ini berarti bahwa $32 \%$ variasi kinerja

PJKR_

http://jurnal.unimed.ac.id/2012/index.php/jpehr/index 
pengurus PPLP dapat dijelaskan oleh variasi pengetahuan manajemen dan komitmen.

Hasil Perhitungan Korelasi Parsial $\mathrm{r}_{\mathrm{y} 1.2}$

\begin{tabular}{ccccc}
\hline Korelasi Parsial & $\mathbf{N}$ & $\mathbf{r}$ & $\mathbf{t}_{\text {hit }}$ & $\mathbf{t}_{\text {tab }}$ \\
\hline $\mathbf{r}_{\mathbf{y} 1.2}$ & 40 & 0.31 & 4.94 & 1.81 \\
\hline
\end{tabular}

Pada tabel di atas menunjukkan $t_{\text {hit }} 4.94$ lebih besar dari pada $t_{\text {tab }}$ sebesar 1.81 sehingga dapat disimpulkan bahwa koefisien koralasi parsial $\mathrm{r}_{\mathrm{y} 1.2}$ sebesar 0.31 adalah sangat signifikan yang berarti bahwa terdapat hubungan antara pengetahuan manajemen dengan kinerja pengurus PPLP, meskipun variabel adaptasi dikontrol.

Hasil Perhitungan Korelasi Parsial $\mathbf{r}_{\mathrm{y} 2.1}$

\begin{tabular}{ccccc}
\hline Korelasi Parsial & $\mathbf{N}$ & $\mathbf{r}$ & $\mathbf{t}_{\text {hit }}$ & $\mathbf{t}_{\text {tab }}$ \\
\hline $\mathrm{r}_{\mathrm{y} 2.1}$ & 40 & 0.26 & 4.19 & 1.81 \\
\hline
\end{tabular}

Pada tabel di atas menunjukkan $t_{\text {hit }} 4.19$ lebih besar dari pada tab sebesar 1.81 sehingga dapat disimpulkan bahwa koefisien koralasi parsial $\mathrm{r}_{\mathrm{y} 1.2}$ sebesar 0.26 adalah sangat signifikan yang berarti bahwa terdapat hubungan antara komitmen dengan kinerja pengurus PPLP, meskipun variabel adaptasi dikontrol.

Berdasarkan koefisien korelasi $\left(\mathrm{r}_{\mathrm{y} 1}\right)$ tersebut juga diperoleh nilai determinasi 0.98. Hal ini berarti bahwa variasi kinerja pengurus PPLP dapat dijelaskan oleh variasi pengetahuan manajemen sebesar 98\%. Temuan dalam penelitian ini sejalan dengan kajian teoritis yang dikemukakan terdahulu bahwa pengurus PPLP yang memiliki pengetahuan manajemen yang baik akan mampu melakukam kinerja dengan optimal. Dengan demikian dapat dikatakan bahwa kinerja pengurus PPLP terkait dengan pengetahuan manajemen yang dimiliki pengurus yang bersangkutan.

Disamping itu, hasil penelitian ini juga menunjukkan bahwa pengetahuan manajemen penting dimiliki dan ditingkatkan oleh setiap pengurus untuk meningkatkan kinerjanya. Jika dilihat secara parsial hubungan pengetahan manajemen dengan kinerja pengurus PPLP dengan mengontrol variabel komitmen diperoleh koefisien korelasi parsial $\left(\mathrm{r}_{\mathrm{y} 12}\right)$ sebesar 0.31. ini berarti bahwa keterkaitan tersebut telah membatasi keterlibatan hubungan terbadap variabel bebas lainnya. Selanjutnya pengontrolan variabel tersebut memperlihatkan kenaikkan keeratan hubungan antara pengetahuan manajemen dengan kinerja, sehingga koefisien korelasi parsial tersebut signifikan. Hal ini karena $t_{\text {hit }}(4.94) \geq$ $\mathrm{t}_{\mathrm{tab}}(1.81)$.

Berdasarkan koefisien korelasi $\left(\mathrm{r}_{\mathrm{y} 2}\right)$ tersebut juga diperoleh nilai determinasi 0.94. Hal ini berarti bahwa variasi kinerja pengurus PPLP dapat dijelaskan oleh variasi komitmen sebesar 94\%. Temuan dalam penelitian ini sejalan dengan kajian teoritis yang dikemukakan terdahulu bahwa pengurus PPLP yang memiliki komitmen yang baik akan mampu melakukam kinerja dengan optimal. Dengan demikian dapat dikatakan bahwa kinerja pengurus PPLP terkait dengan komitmen yang dimiliki pengurus yang bersangkutan.

PJKR_

http://jurnal.unimed.ac.id/2012/index.php/jpehr/index 
Disamping itu, hasil penelitian ini juga menunjukkan bahwa komitmen penting dimiliki dan ditingkatkan oleh setiap pengurus untuk meningkatkan kinerjanya. Jika dilihat secara parsial hubungan komitmen dengan kinerja pengurus PPLP dengan mengontrol variabel komitmen diperoleh koefisien korelasi parsial $\left(\mathrm{r}_{\mathrm{y} 21}\right)$ sebesar 0.26. ini berarti bahwa keterkaitan tersebut telah membatasi keterlibatan hubungan terbadap variabel bebas lainnya. Selanjutnya pengontrolan variabel tersebut memperlihatkan kenaikkan keeratan hubungan antara komitmen dengan kinerja, sehingga koefisien korelasi parsial tersebut signifikan. Hal ini karena $t_{\text {hit }}(4.19) \geq t_{\text {tab }}(1.81)$.

Berdasarkan persamaan regresi ganda menunjukkan bahwa diantara kedua variabel bebas tersebut yang paling tinggi memberikan peningkatan kinerja pengurus PPLP apabila kedua variabel bebas dinaikkan satu unit adalah variabel pengetahuan manajemen 2.58 dan komitmen 0.03 .

Selanjutnya koefisien korelasi ganda secara bersama-sama antara pengetahuan manajemen dan komitmen dengan kinerja pengurus diperoleh $\left(\mathrm{R}_{\mathrm{y} 12}\right)$ sebesar0.32. Pengujian signifikansi melalui uji $F$ diperoleh $F_{h i t}$ sebesar 8.94 lebih besar dari $\mathrm{F}_{\text {tab }}$ sebesar 4.10 sehingga koefisien korelasi ganda $\left(\mathrm{R}_{\mathrm{y} 12}\right)$ dinyatakan signifikan yang berarti bahwa semakin tinggi pengetahuan manajemen dan komitmen secara bersama-sama makin tinggi pula kinerja pengurus PPLP. Sebaliknya, makin rendahnya pengetahuan manajemen dan komitmen makin rendah pula kinerja pengurus PPLP.

Berdasarkan koefisien korelasi ganda $\left(\mathrm{R}_{\mathrm{y} 12}\right)$ tersebut, akan diperoleh koefisien determinasi sebesar 0.32 sehingga dengan demikian temuan dalam penelitian ini menunjukkan pentingnya variabel pengetahuan manajemen dan komitmen untuk meningkatkan kinerja pengurus PPLP oleh karena secara bersama-sama kedua variabel tersebut menjelaskan variasi kinerja pengurus PPLP sebesar 32\%. Hal ini sejalan dengan teori masing-masing variabel bebas yang telah dijelaskan pada bagian terdahulu.

Secara keseluruhan dapat disimpilkan bahwa setelah dilakukan pengujuan secara statistik terhadap data empirik yang telah diperoleh dari lapangan dapat dikatakan bahwa kedua variabel bebas yang diajukan yaitu variabel pengetahuan manajemen dan komitmen berkorelasi positif secara signifikan dengan kinerja pengurus PPLP.

\section{Simpulan}

Berdasarkan hasil penelitian, dan uji hipotesisi diperoleh kesimpulan bahwa:

1. Terdapat hubungan yang signifikan antara pengetahuan manajemen dengan kinerja pengurus PPLP di Sumatera Utara. Hal ini berarti bahwa makin baik pengetahuan manajemen makin baik pula kinerja pengurus PPLP. Sebaliknya, makin rendah pengetahuan manajemen makin rendah pula kinerja pengurus PPLP.

2. Terdapat hubungan yang positif antara komitmen dengan kinerja pengurus PPLP. Hal ini berarti bahwa makin baik komitmen makin baik pula kinerja pengurus PPLP di Sumatera Utara. Sebaliknya, makin rendahnya komitmen makin rendah pula kinerja pengurus PPLP.

PJKR_

http://jurnal.unimed.ac.id/2012/index.php/jpehr/index 
3. Terdapat hubungan positif secara bersama-sama antara pengetahuan manajemen dan komitmen dengan kinerja pengurus PPLP. Hal ini berarti bahwa makin baik tingkat pengetahuan dan komitmen makin baik kinerja pengurus PPLP. Sebaliknya, makin rendah pengetahuan manajemen dan komitmen makin rendah pula kinerja pengurus PPLP di Sumatera Utara.

\section{Rujukan}

Armstrong, M. dan Barron, A., 1998. Performance Management, London: Institute Of Personal and Development.

Bloom, S., Benyamin, at al, 1981. Taxonimy of educational Objectives, New York: Longman, 1981.

Dessler, Gary, 2003. Human Resource Management, 9th Ed., Singapore: Prentice Hall Pearson Education, Inc.

Fadli, Zein, 2016. Hubungan Teknologi Informasi Dan Komunikasi Dalam Menunjang Kinerja Koni Provinsi Dan Induk-Induk Organisasi Cabang Olahraga Sumatera Utara, Jurnal Ilmu Keolahragaan, 15 (1): 26-37.

Handoko, T. Hani, 2000. Manajemen Personalia dan Sumberdaya Manusia. ed. 2, Yogyakarta: FE UGM.

Harsuki dkk, 1996. Paper Akademik untuk Penyusunan Undang-Undang Keolahragaan, Jakarta; Kantor Menpora.

Hasibuan, Malayu S.P., 2005. Manajemen Sumberdaya Manusia, Jakarta: Bumi Aksara.

Imran Akhmad, 2013. Kinerja Pelatih Sekolah Khusus Olahragawan Negeri Ragunan tahun 2011, Jurnal Pengabdian Kepada Masyarakat, 19 (73): 58-67.

Luthans, Fred, 1996. Organization Behavior, 7th ed. Singapore: McGraw-Hill, Inc.

Robbin, Steppen P, 1996. Perilaku Organisasi: Konsep, Kontroversi, Aplikasi, Terjemahan Hadya Pajaatmaka, Jakarta: PT. Prenhallindo.

Siswanto, Joko, 1996. The Assessment ang the Develovment of the Innovative Spirit of Tecknic Working in Industrial Manufacturing Companies in Indonesia: A Models Develovment and Preliminary Findings, Optimizingxcellence in Human Resource Development, Utami Munandar dan Conny Semiawan (ed), the 4th Asia-Pasific Conference on Giftedness, 4-8 Agustus.

Setro, Samuel C, 1997. Modern Management, Seventh Edition, New Jersey: Prentice Hall International Inc.

Suriasumantri, Jujun. S., Filsafat ilmu; Sebuah Pengantar Populer, Jakarta: Pustaka Sinar Harapan, 1988.

Sutrisno Hadi, 1993. Metodologi Research, Jakarta: Andi Offset.

Sudjana, 2002. Metode Statistika, Bandung: Tarsito.

Wahyudi, Erwan dan Imam Marsudi, Manajemen Kinerja Pengurus KONI Kabupaten Lamongan, Jurnal Prestasi Olahraga, 1 (1) 11-19.

PJKR_

http://jurnal.unimed.ac.id/2012/index.php/jpehr/index 